\title{
DISKUSSIE
}

\section{DIE ADRES VIR DIE VERSLAG VAN KERKVISITASIE}

LESER sê dat in hulle Klassis 'n Reglement van orde geld wat die visitatore opdrag gee om haarfyn verslag van hulle bevindinge en aanbevelings in ' $n$ volgende klassisverslag te doen. Die verslag word aan die klassis gerig en die kerkraad ontvang 'n afskrif. Hulle mag die verslag op die klassis bestry, maar sodra die klassis dit aanvaar het, moet die kerkrade die aanbevelings uitvoer as komende van die klassis. Leser voel onseker oor hierdie praktyk, maar oordeel dat die visitatore deputate van die klassis is en geen ander werkswyse moontlik maak nie. Hy wil graag daaroor die mening van In die Skriflig hê.

\section{Opmerking.}

In die Skriflig wil graag diensbaar wees aan die gereformeerde teologie. Ons aanvaar dat Christus sy Kerk deur sy Woord regeer. Ons kan daardie Woord help oopmaak - maar dit bly die geroepe dienaars wat die Woord moet toepas. Gevolglik bly dit ook die Woord wat hulle bedien, wat die kerk moet regeer.

\section{Kerkvisitasie.}

Die begrip kerkvisitasie beteken letterlik: 'n besoek by of ondersoek na 'n kerk (gemeente). Die kernprobleem is seker dadelik: wie besoek? Is dit twee daartoe benoemde dienaars - of is dit die klassis wat deur middel van twee deputate visitasie doen?

Artikel 44 K.O. sê: „Die Klassis moet minstens twee van die oudste mees ervare en geskikte bedienaars van die Woord, as visitatore benoem om in alle kerke van die klassis gereeld kerkvisitasie te hou..." Die opmerklike is dat hierdie broeders deur ' $n$ klassis benoem word; dat hulle bepaaldelik visitatore genoem word; dat hulle ontmoeting die naam kerkvisitasie ontvang.

Daar is Bybelse voorbeelde van hierdie beginsel: die apostels het gemeentes so besoek, vgl. Hand. 15: 41. Daar het geen permanente klassis- of kerkverbandstruktuur agter die apostoliese besoeke bly leef het nie. Daar was 'n byeenkoms van dienaars en die kerk van Jerusalem, daarna gaan die apostel en hy versterk die gemeentes kragtens en in sy apostoliese diens - en hy bly altyd bekommerd oor hoe dit gaan by die ander gemeentes waar hy nie teenwoordig is nie. Hier kom die visitasie dus baie konkreet neer op bediening; die visitator-apostel bedien sy amp as 'n diens van vermaning, vertroosting, lering, opskerping, ens. Hy doen dit kragtens die roeping van God, omdat Christus hom stuur om die gawe van regering te bedienen nie omdat 'n kerkvergadering sy sender is aan wie hy hom moet verantwoord nie. Deputate kragtens art. 49 K.O. tree op as persone met geen regeermag nie. Visitatore gaan in die amp en hulle het leeren regeeropdrag.

Die kerkvisitasie het 'n lang ontwikkeling deurloop. Reeds ge- 
durende die Middeleeue het die biskop (opsiener) 'n toer onderneem om te kan bedien en ondersoek in te stel. Hierdie visitasie is dus ook gedoen kragtens die diens of amp van opsienerskap - en nie om 'n verslag aan 'n derde instansie te bring nie. Die praktyk is tot onlangs (moontlik nou nog) ook in die Anglikaanse Kerk gevolg: the bishop's visitation tour. Weliswaar ontleen die biskoppe in die hiërargiese stelsels hulle bevoegdheid aan die hoogste biskop, die pous of koning.

Ook die Lutherse het die praktyk van visitasie deur 'n hoofopsiener of „superintendent" voortgesit. Oënskynlik lyk die prosedure van die visitasie nogal baie op wat ons ken - selfs i.v.m. die bekende vrae waarop die gemeente moet antwoord. Die superintendent skryf sy verslag in die kerkraadsnotule wat die aanwesige predikante en kerkraadslede moet onderteken en van sy bevindinge (L.W. nie sy aanbevelinge nie) doen hy verslag by die ringsinode (Vgl. H. Bouwman, Geref. Kerkrecht II 1934, p. 160 v.). Bouwman noem dit 'n tipies kollegialistiese visitasie wat uitgegaan het van „hoër besture” — al het dit goeie resultate afgewerp.

Calvyn het die visitasie ook behou en so ingerig dat 'n kommissie van vier, twee aangewys deur die magistraat en twee verkies deur die predikante, al die parochië sou besoek - en dan terstond indien nodig sou vermaan, onderwys gee, die eer van die Here bevorder, ens. Die visitasie moet egter nooit die vorm van geregtelike ondersoek word nie. Dit moes slegs 'n middel wees om die ergernisse weg te neem. Weliswaar is daarna 'n „verslag" aan die ring van predikante gedoen. Die visitasie het in die parochie afgespeel en daarna is 'n bloot informatiewe verslag aan die kring van predikante gelewer. Hierdie visitasie het inderdaad buite die konsistorie omgegaan.

Knox ontwikkel die visitasie sodanig dat dit 'n ondersoek oor predikante en gemeentes word en daarna word verslag in die General Assembly gedoen. Bouwman verwerp hierdie superintendentebeginsel as in stryd met die Gereformeerde Kerkreg (a.w., p. 162).

Die Gereformeerdes was van huis uit bedug vir enige vorm van hiërargie. Art. 84 K.O. staan sentraal in die gereformeerde denke: „Geen kerk mag oor ander kerke, geen bedienaar van die Woord oor ander bedienaars ... enige heerskappy voer nie." Daar was gevolglik weerstand teen die benoeming van visitatore uit vrees vir die gevare van hiërargie - en die kerke het liewer onderling op mekaar toesig gehou in die klassis (vgl. die beginsel in art. 41 K.O.) d.m.v. die rondvraag deur die voorsitter. Part. Sinodes het aanvanklik benewens die rondvraag op die klassis visitatore benoem - en uiteraard het hulle nie die hele balas in rapporte na die sinodes teruggevoer nie. Teen 1586 het die kerkvisitasie (art. 44 K.O.) langs die onderlinge toesig op die klassis (art. 41 K.O.) beslag gekry. Gelyktydig is egter die idee van 'n superintendentskap opnuut veroordeel. Die taak van die visitatore t.o.v. die dienaars en die lidmate is duidelik omskryf: Hulle moet eers in die besonder vermaan tot verbetering en daartoe alle hulp bewys ,en zoo het niet helpe, de classicale vergadering aandienen" (Bouwman, a.w., p. 165).

Kerkvisitasie bedoel dus primêr om die suiwerheid van die leer 
te handhaaf, tweedens om die goeie orde sy loop te gee en om die kerke met goeie raad te steun. Dit bly gereformeerd so lank die vryheid en selfstandigheid van die plaaslike kerk gehandhaaf word en rus op die dieper eenheid in Christus wat in kerkverband beleef en uitgeleef word. Independentisme of willekeur t.o.v. die leer en die Skrif is radikaal uitgesluit.

\section{Visitasie word gedoen deur visitatore.}

Hoewel die visitasie regstreeks voorvloei uit die eenheid wat die kerke met mekaar onderhou in leer en regering, gaan die visitasie as visitasie uit van twee bedienaars van die Woord wat wel deur middel van die klassis aangewys is - maar gaan optree kragtens die diens waarin hulle staan. Besondere vereistes stel art. 44 K.O. daarom aan hulle. Tereg wys Bouwman hoe gevaarlik kan visitasie-reglemente met vasgestelde vrae en voorskrifte word. Hy merk op dat die kwaliteit van die visitator die sukses bepaal: „Mag de visitatie niet ontaarden in een inquisitoriaal onderzoek... De ware visitator moet zijn een menschenkenner, die een juisten blik heeft in het leven ... en die, bezield met de liefde van Christus, gaarne wil medewerken (ek kursiveer) tot het welzijn der kerk, en den opbouw van het lichaam van Christus" (a.w. p. 173).

Artikel 44 K.O. stel dan ook die ondersoek wat die visitatore doen en gee meteen hulle opdrag om mee te werk met dié kerk wat hulle besoek - Waar hulle nalatigheid aantref, moet hulle „betyds broederlik kan vermaan en met raad en daad alles kan help reël wat bevorderlik is vir die vrede, die opbou en belange van die kerk."

Indien ' $n$ visitator eers sy bevindinge by die klassis moet aandien om sy aanbevelings te laat sanksioneer, maak hierdie woorde van art. 44 K.O. geen sin nie.

(1) Art. 44 K.O. bind die visitatore aan die roeping wat Christus met hulle diens of amp op hulle gelê het en kragtens die kerkverband word hierdie diens- of amp-gawes aan die kerk in 'n bepaalde en afgeronde geleentheid, genoem kerkvisitasie, gegee. Dit is iets wesenlik anders as die deputate-beginsel in art. 49 K.O.

(2) Die visitatore werk saam met die mede-dienaars (ouderlinge en diakens) met die oog gerig op die opbou van die plaaslike kerk waar die visitasie plaasvind (vgl. Ef. $4: 11 \mathrm{v}$ ). Dit kan slegs beteken dat hulle hulle bevindinge ook aan die kerk meedeel. Wanneer hulle moet vermaan, sê art. 44, moet dit sonder versuim geskied. Enige „raad" of „daad" wat nodig is vir die opbou van die liggaam van Christus moet terstond gegee word. Dan maak die begrip dat visitatore ,help reël" sin.

(3) Dit hou wel in dat die visitatore geroepe is, om wanneer 'n kerk weier om by die Skrif, leer of kerkorde te konformeer die saak kragtens art. $31 \mathrm{~K} .0$. na die Klassis te neem.

\section{Die adres vir die visitasie.}

Die adres vir visitasie is in die Skrif en in art. 44 die kerk wat 
besoek word. Van 'n rapport (soos by art. 49 K.O.) maak art. 44 K.O. geen melding nie. Dit sluit egter nie 'n rapport uit nie. Die adres vir die eintlike inhoudelike rapport is egter die kerkraad waar visitasie gedoen is. Die ideaal is miskien juis dat die rapport daar ter vergadering mondeling gegee word: bevinding, aanbeveling en besluit daarop. Die ontmoeting van die visitatore met die gemeente is eintlik ook die verslag - of anders 'n geskrewe rapport met bevindinge en aanbevelinge wat voorgelees word. In goeie kerkverband sal die visitatore en kerkraad mekaar op hoogte hou oor wat die kerkraad met bepaalde ernstige aanbevelings maak. As dit verkeerd gaan, lê die weg van art. 31 K.O. oop om die regering van Christus in sy kerk te dien.

Weliswaar benoem die Klassis visitatore om visitasie te hou Daaroor moet rapport na die klassis gaan: Die kerkvisitasie is daar en daar gehou, dit het goed verloop - of indien nodig, spyt dit die visitatore dat hulle die oordeel van die klassis moet vra oor 'n besluit van die kerkraad in stryd met die advies wat hulle die kerkraad gegee het.

Waarom die kerkraad moet handel op advies van visitatore en nie die klassis op 'n visitasierapport nie:

(1) Die herders in die kerkraad is geroepe om die plaaslike kerk te regeer en elke saak wat die kerk raak moet eers daar behandel en afgehandel wees voordat dit na die klassis kan gaan (art. 30). Visitasie geskied juis om te verhoed dat onstigtelikhede en twiste ens. verder gaan. Indien die klassis eers oor die advies van visitatore moet besluit voordat die kerkraad handel, tas die visitasie die roeping en selfstandigheid van die plaaslike kerk in sy wese aan.

(2) Indien die visitasie oor vertroulike dinge gaan - of byvoorbeeld van so ' $n$ aard is dat die eer van gelowiges of die gemeente daarmee gemoeid is - en die visitasie-rapport sou sondermeer die materie aan die klassis rapporteer, sou 'n kerk wat hulp nodig het die visitasie vrees en die visitasierapport sou ook direk in stryd wees met Skrifbeginsels soos Matt. 18 : 15 v. Indien daar "moeilikhede" in 'n gemeente was en die visitasie het versoening gebring, watter reg is daar om die materie verder te gaan ,rapporteer", behalwe as die „klassis" as die „hoof" oor die gemeente en visitatore beskou word?

(3) Hoewel die metode van kommissie-regering nogal wyd verbrei is, is dit nie eie aan die gereformeerde kerkregering om die bevindinge van twee persone vir die rekening van 'n klassis te neem nie. Hoe kan 'n klassis 'n visitasie-rapport inhoudelik ,aanvaar" as die klassis nie self die visitasie gedoen het nie? Hy kan slegs aanvaar dat die visitasie gedoen is - tot watter mate dit bevrediging gegee het. Dit sou verder moontlik wees om bloot informatief 'n samevattende beeld van die kerklike lewe te gee, hoewel dit al weer $\mathrm{na}$ iets anders as die bedoeling van art. $44 \mathrm{~K}$.O. neig.

(4) Indien die klassis hom met 'n visitasie-rapport gaan vereenselwig op die getuienis van twee visitatore - hoedanig is sy verhouding tot die kerk waar visitasie gedoen is, indien die verteenwoordi- 
gers van dié kerk die korrektheid van die rapport of die wysheid van aanbevelings betwis?

\section{Voorbehoud.}

Bostaande beredenering het uitgegaan van die gewone of gereelde kerkvisitasie en van 'n visitasie wat deur 'n plaaslike kerk aangevra is omdat hy die hulp van 'n kerkverband nodig het. Vanselfsprekend kan daar gevalle van verval, verharding, onvermoë, moedswil of chaos voorkom wat die klassis noop om inisiatief te neem en te doen wat des kerkraads was. In buitengewone gevalle sal die visitasie sowel as die rapport ' $n$ vorm aanneem wat by die saak en die omstandighede pas.

B.S 